\title{
Pre-Extension Demonstration and Evaluation of Engine Driven Soya Bean Thresher in East Wallaga Zone of Oromia, Ethiopia
}

\author{
Girma Ajama $^{1^{*}} \quad$ Galgalo Kibi2,3 \\ 1. Agricultural Extension Research, Bako Agricultural engineering Research Center, P. O. Box 07, ETHIOPIA \\ 2. Agricultural Machinery and farm power, Bako Agricultural engineering Research Center, P. O. Box 07, \\ ETHIOPIA \\ 3. Center director, Bako Agricultural engineering Research Center, P. O. Box 07, ETHIOPIA
}

\begin{abstract}
With the aim of circumventing challenges faced farmers in soya bean threshing operation a demonstration of new soya bean thresher was conducted in Guto Gida and Gida Ayana woredas in a total of four kebeles. The thresher was demonstrated at farmer training center as well as on farmers' field and evaluated for its performance against existing farmers practices by sixty participating farmers of both sexes who were members of four farmer's research groups. All valuable data were collected through survey, measurement, count and FGDs and were analyzed in descriptive statistics. From the analysis, demonstrated soya bean thresher observed to have a capacity of about five and half quintals per hour and a threshing efficiency of 85 percent with the safer limit of breakage percent ranges from 2 to 3. This result could support the conclusion that adoption and use of demonstrated machine. Therefore it was recommended that the office of agriculture and natural resource development of the districts to further scaling up the technology to other areas to benefit quite significant number of farmers.
\end{abstract}

Keywords: DA, Farmers, Demonstration, Soya bean, Soya bean thresher, traditional threshing,

DOI: $10.7176 / \mathrm{JPID} / 61-03$

Publication date: January $31^{\text {st }} 2022$

\section{Introduction}

Soya bean (UK) or soybean (U.S.) is a leguminous herbaceous annual plant that the Food and Agriculture Organization (FAO) classified it yet as oil crop rather than pulse. The scientific term associated with it, is Glycine max. Anthropologists, archaeologists, historians, and other scholars believe that soya bean was first domesticated in East Asia with Chinese farmers reportedly the first people to grow the crop some five thousand years ago (Boerma and Specht, 2004). From there, it extended into neighboring regions such as the Russian Far East, Korean peninsula, Japan and later widespread to North America, Europe then to South and Central America. Over time, in the mid-1 $1{ }^{\text {th }}$ century, the crop was introduced to Africa from china along the east coast of Africa (CGIAR, 2005). Over a period of $19^{\text {th }}$ century, the crop was introduced to Africa from china along the east coast of Africa

The first effort to establish soya bean in Africa was made in Algeria when it was grown at a government botanical station in 1896. The next record of soybean cultivation in the continent was in 1903 when they were grown in South Africa at Cedara in Natal and in the Transvaal. In about 1907 soya beans were introduced to Mauritius Island and Tanzania by German agriculturalists. Since then a dramatic and tremendous interest in growing this crop in Africa was raised (Shurtleff \& Aoyagi, 2009). Currently South Africa is the largest producer of soybean in African continent, followed by Nigeria, Zambia and Uganda. Distantly followed Benin, Malawi, Zimbabwe and Sudan, Ethiopia has also experienced sizable soy bean production expansion, according to data recorded in the world soya bean production statistics compiled by FAO (2016)

According to Bukill (1935), soya bean (Glycine Max) cultivation reached Ethiopia in the early 1950s although it is not known with certainty who introduced the crop to the country. But attempts to grow the crop at that time failed owing to the low yields obtained. In late 1960s trials re-started and with the introduction of new highyielding cultivars in the 1970s, new interest was generated. Most importantly, soybean production on a relatively large scale was undertaken in 1980s when the country's socialist regime looked to develop certain state farms in Wollega, Gojjam, Kaffa, Awassa, Shashemene and Awash. From then on the soybean does very well in Ethiopia. Over the seasons from 2014/15 to 2019/20 soya bean production posted a remarkable surge instigated by the government's quest to improve production of the crop through the second five-year Growth and Transformation Plan for example. The rapid increase in soya bean production in Ethiopia is also attributed to the country's strategic location closer to the world's largest consumers of soybean and soybean products that appealed the nation greatly to target soya bean production as potential export commodity (Birhanu et al., 2018)

Ethiopian government, via GTP II, program targeted to increase the average productivity of soya bean by $49 \%$ between 2015 and 2020 and volume of production from 0.72 million quintals to 1.2 million over the same period to meet the demand of the market by creating a linkage with the industry and export market (GTP II, 2015). Records obtained from CSA for the period mentioned above revealed that area under soya bean and its production exceeded the figures envisaged by twofold. During this period, the area cultivated under soya bean increased from $35,259.76$ hectare to 163629 as more farmers were venturing into its farming. The corresponding annual 
production quantities in that time span have ranged from 721, 837.45 to $\mathbf{3 , 7 6 8 , 6 9 0}$ quintals (CSA, 20015-2019). The same records reveal that there were closer to 123 farmers grow the crop in 2019/20 for a raft of uses range from human food, to animal feed and to industrial raw materials. Exports jumped from 30,000 metric tons in $2015 / 16$ to around 80,000 metric tons in 2019/20 in large part because of increased demand.

Regionally, Amhara Oromia, Beneshangul Gumuz and Gambela are at the moment, the largest producer while Oromia is by far in the forefront constituting 51\% share of the total national production (MoARD, 2010). Oromia agricultural office put 2019/20 soya bean production of the region at 232,037 quintals, noting that output has risen from 1200 quintal in 2014/15. The acreage ploughed for the crop and number of farmers engaged in soya bean production was growing year after year. Despite the high level of production of soya bean in Ethiopia, its harvesting and threshing operation remains among the major challenges to holders most notably in western part of the country.

Harvesting and threshing operations are known as crucial and influential processes on quantity, quality and production cost of soybean (Manuwa, 2011). A report by Alemu and Tesema (2010) identified inadequate appropriate harvesting technology as a major problem that may constrain soya bean production in Ethiopia. This made it difficult for area expansion as far as production is concerned. Khan (1971) and IDRC (1976) added that the problem of harvesting and threshing is worsened with the introduction of more productive rice varieties because of the greater amount of crop that has to be handled.

In Ethiopia, soya bean is threshed by stick beating and by being trodden under hooves of animals as no proper mechanical thresher was available. There is little doubt that these processes are tedious and labor intensive. In Ethiopia, It was found that the operation might pull children out of school since processing food for survival takes priority over education in subsistence farming households

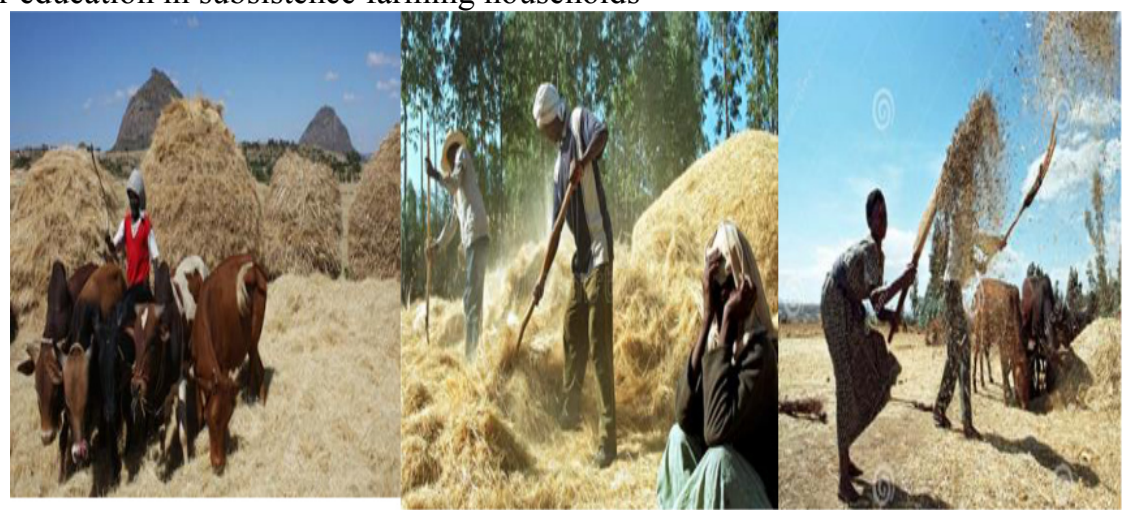

Figure 1. Traditional threshing

The practice require smeared floor and transportation of materials from harvested field to threshing floor especially if the floor was prepared at home garden, leading to involvement of man power, time, and hence cost of operation. If threshing is not done within the stipulated time, all efforts made by farmers and inputs given to crop go wasted. Added to that, traditional method of threshing by animal and humans results in huge losses (Asfaw et.al, 2011) due to the grain being broken or buried in the earth. Hence an efficient cheap mechanical thresher would definitely be a welcome relief

In response to these challenges, several efforts have been made, and are still being made by the research institutes and other organizations. Very recently Bako agricultural engineering research center has adapted and evaluated IITA engine operated Multi-crop thresher for soya bean threshing with a particular focus on transforming the arduous, tediousness, unsanitary and inefficiency attributes associated with traditional threshing methods. The machine was tested in the center and the following optimum performance indices were obtained when soya bean panicles were processed at the best combination of $13 \%$ moisture content $5 \mathrm{~kg} / \mathrm{min}$ feeding rate and $700 \mathrm{rpm}$ cylinder speed: threshing capacity $603.63 \mathrm{~kg} / \mathrm{hr}$., threshing efficiency $100 \%$, mechanical grain damage $4.38 \%$ and cleaning efficiency $82.24 \%$. This indicates that the machine has the advantage of high removal rate and low breakage, which would cut down the threshing time and save labor cost at a time.

In the study area, promotion of this kind of technology is rationalized due to the need to increased soya bean production, inefficiency of manual threshing, seasonal drudgeries of women and children and subsequent losses. Therefore, demonstration and promotion of adapted soya bean thresher is recommended in east wollega with the specific objectives of creating awareness among farmers about the availability of the technology and its multifarious uses; evaluating field performance of the machine in comparison with that of traditional practices and collecting feedbacks from participants to further improve the technology. 


\section{Research Methods}

\subsection{Description of research area}

The present demonstration activity was conducted for a two consecutive years in East Wollega zone, Ethiopia's Oromia region. With 10\% share, East Wollega is a second leading zone in Akuri Atar (Ethiopian soya bean) production in the region after Illu-ababor zone (Hailegiorgis, 2010). Estimation indicates the area harvested in 2019 season was at a record of 98.2 million ha, up 4.2\% from 2015/16 season, with cultivation mainly concentrated in the Gida Ayana, Guto Gida, Diga, Sasiga and Limu ( WoANR), 2019); Following their standing out in intensity of soya bean production, the first two districts were purposively selected for the current research. Descriptions of each area were given below:

\section{Gida Ayana}

Gida Ayana is a district located $444 \mathrm{~km}$ far away from Addis Ababa and $112 \mathrm{~km}$ north of Nekemte, the capital of east wollega zone. It is bordered by Guto-wayu district in the south direction, Amhara region in the north, Limu in the west and Kiramu and Abe-Dongoro districts in the east direction. Administratively, the district is subdivided into 19 rural kebeles (sub-districts) and 6 towns that agro-climatically categorized as $50 \%$ Kola, $48 \%$ Woina Dega, and 2\% Dega. The average yearly rainfall is $1739.15 \mathrm{~mm}$, with a rainy season during May to September and a relatively dry period from December to March. There is no high variation of temperature throughout the year but the maximum temperature is in February and March. The district is known for its production of soybeans and other leguminous, Cereals, vegetables and some important fruit crops like mango, avocado, banana etc. (Ethiopian Central Statistical Agency (CSA), 2014). Available soybean production data from unpublished report of the districts shows that the Gida ayana district recorded a total production figure of 5 tons, 6 tons and 8 tons from a total of 5ha 6ha and 8ha in 2017,2018 and 2019 respectively with little scientific input. In Gida Ayana, the entire operations in crop production and animal husbandry were still performing with bare hands or using very rudimentary farm tools powered with human and animals, like many of their counterparts across Ethiopia. As concerned to soya bean threshing, here farmers commonly use conventional method involves animal hoofing and beating with sticks depending upon capacity, lot size and situation.

\section{Guto Gida}

It is found in the Oromia region towards west direction at a distance of $331 \mathrm{~km}$ far from Addis Ababa, the capital city of Ethiopia. The district's climate is sub-tropical type with an annual mean temperature oscillates between 1524 degree Celsius and receives uni-modal rainfall ranging from 700 to $900 \mathrm{~mm}$ per annum. Livelihood of people in this area is farming which done on subsistence basis with many small land size holdings and poor mechanization. However, some farmers are engaged in commercial farming cultivating large areas of maize, soybean and groundnut. Staple food crops include maize, sorghum finger-millet. Legumes such as groundnuts, soybean and vegetables like cabbage, spinach and onion constitute the main cash crops. Annual crops are predominant and rainfed agriculture is mainly practiced using draught power. As far as livestock is concerned, cattle, sheep and horses are the major types of livestock kept by the different households.

It is found in the Oromia region towards west direction at a distance of $331 \mathrm{~km}$ far from Addis Ababa, the capital city of Ethiopia. The district is temperate-humid with an annual mean temperature oscillates between 17 24 degree Celsius and receives uni-modal rainfall ranging from 700 to $900 \mathrm{~mm}$ per annum. Livelihood of people in this area is farming which done on subsistence basis with many small land size holdings and poor mechanization. However, some farmers are engaged in commercial farming cultivating large areas of maize, soybean and groundnut. Staple food crops include maize, sorghum finger-millet. Legumes such as groundnuts, soybean and vegetables like cabbage, spinach and onion constitute the main cash crops. Annual crops are predominant and rainfed agriculture is mainly practiced using draught power. As far as livestock is concerned, cattle, sheep and horses are the major types of livestock kept by the different households.

\subsection{Site and farmer selection and organization of FRGs}

By holding meeting for experts from District Agriculture and Natural Resource Development office, DAs and local leaders multi-disciplinary researchers from the Bako Agricultural Engineering Research Centre explained the role of the farmers in the research and development process, the current agriculture extension program and inherent problems, the need to make research and extension more client oriented. This meeting has culminated in the purposive selection of four research sites namely Uke Badiya, Tulu Lencha, Warabo, and Andode Dicho kebeles depending on their greatest potential and access to road.

Table 1. Research sites and participants

\begin{tabular}{lclll}
\hline & & \multicolumn{3}{l}{ No of participant } \\
\cline { 3 - 5 } Intervention District & Number of kebeles & Male & Female & Total \\
\hline Gida Ayana & 03 & 33 & 12 & 45 \\
Guto Gida & 01 & 11 & 4 & 15 \\
\hline Total & 04 & 44 & 16 & 60 \\
\hline
\end{tabular}

From those kebeles a selection of 60 households were carried out focusing soya bean production capacity, 
willingness of farmer to participate in the research, interest to work in group and share experience to other farmers. In the selection of participants there was consideration for gender justice. The farmers selected for the research were finally encouraged to teamed up together to establish four farmer research groups with a membership of 15 households each. Four arbitrary farmers from each group and three farmers' training center (FTCs) were selected to host the demonstration. Subsequently extension activities like training and demonstration were held to create awareness among those selected farmers, DAs and agricultural extension and mechanization experts about the technology and its various uses. Researchers and Technician staff from the Bako Agricultural Engineering research center (BAERC) served as the resource persons and facilitators of the events.

\subsection{Types and method of data collection}

Sorts of methods of data collection were used. A rapid survey was conducted to capture data on traditional threshing methods time and number of laborers and oxen required in that methods whereas measurements were carried out to gather data related to mass of whole soybean panicle feed in to the machine, grain threshed, Quantity of grain broken in threshing course, un-threshed soybean crop, the time spent in threshing to gauge machine's threshing efficiency, output capacity and the percentage of soya bean grain breakage by formula 1, 2 and 3 . Number of farmers who participated in training and demonstration organized gathered through count. On the other hand what participants thought and how they felt about the technology demonstrated as compared with the traditional practices were probed through FGDs. Field notebook which was used as an interview guide and data recording sheet for the researcher.

$$
\begin{aligned}
& \text { Threshing efficiency }(\%)=\frac{Q_{T}}{Q_{T}+Q_{U S}} \times 100 \ldots \ldots \ldots \ldots \ldots \ldots 1
\end{aligned}
$$

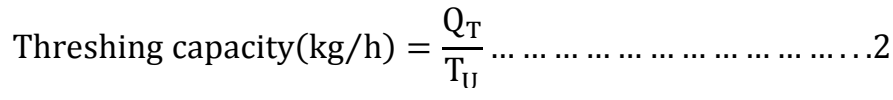

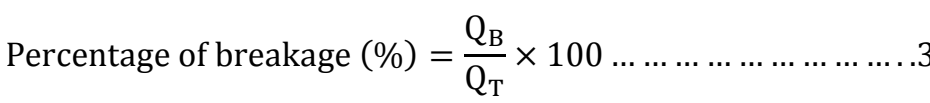

where:

$$
\begin{gathered}
\mathrm{Q}_{\mathrm{T}}=\text { Quantity of threshed grain }(\mathrm{kg}) \\
\mathrm{Q}_{\mathrm{B}}=\text { Quantity of broken grain }(\mathrm{g}) \\
\mathrm{Q}_{\mathrm{B}}=\text { Quantity of unthreshed grain remain in pods }(\mathrm{kg})
\end{gathered}
$$$$
\mathrm{T}_{\mathrm{U}}=\text { time utlized in threshing operation }(\mathrm{min})
$$

\subsection{Data Analysis tools}

The collected data were statistically analyzed using descriptive statistics such as percentages, means, and standard deviations. Excel spread sheet was used to compute raw data. Concomitantly the data collected from focus group discussion and personal interview were transcribed verbatim.

\section{Result and Discussion}

\subsection{Survey result}

Several methods of threshing exist. Some continue to be used today while others evolved with advancements in technology. A separated rapid survey conducted identified animal trampling and stick beating in the localities and these methods included in this research to evaluate the comparative advantage of the introduced thresher against both.

\section{Animal trampling}

A crew of animals is allowed to treadle on the soya bean stalk spread on threshing ground, often coating with a thin layer of cattle dung and sometimes covering with mats or plastic sheets. According to participant farmers saying, this method takes on average ten oxen-cum-five persons a day to produce one ton output of soya bean grain. Threshing of soya bean undertaking with oxen is less burdensome and safer for seed purpose point of view. Nonetheless it employs huge loss due to mixes with dung, urine and the amount eaten by livestock when they thresh the crop. Absence of sufficient livestock for trampling forces prolonging threshing period thereby increasing loss due to shattering, pests and rotting of grains. If threshing animals are not available, the farmers will thresh by stick beating little by little thereby exaggerating the loss.

\section{Beating by stick}

Beating involves pounding panicles of soya bean crop with wooden stick on the ground. Some other growers thresh soya bean by putting the whole soya bean plant inside jute bags and beat open their pods which are usually already dry with a hard stick. This work requires enormous labor than others and damages grain. In a survey, farmers presumed that with this method of threshing 10-12 persons are required for 8 hours-day length. However, farmers 
claimed that it threshes more grain from the same quantity of soya bean, speedier than other conventional methods, and that more cleanly than the animal trampling. Most threshing jobs take several days, so they assist each other by forming a small farmers' group in their farms. In return for help threshing, they offered payment to each other in the form of a day's worth of food or liquor. In this operation participants are mostly males youth as it demands more energy

\subsection{Farmers' Awareness Creation}

The means used to create awareness among farmers was training sessions and technology demonstration in the form of field days. The intension is to make the technology better known and more widely accepted by potential users since they are not versed in how to use and maintain the machine

\section{Training of farmers and agricultural extension workers}

In total, about 70 people participated in the training program conducted for 4 days. Among the key topics discussed were the overview of the farm mechanization program, proper management practices in soybean farming, the tedious nature of traditional threshing, and basic operation involved in using the technology, which process soya beans in a fraction of the time it takes to do it by hand

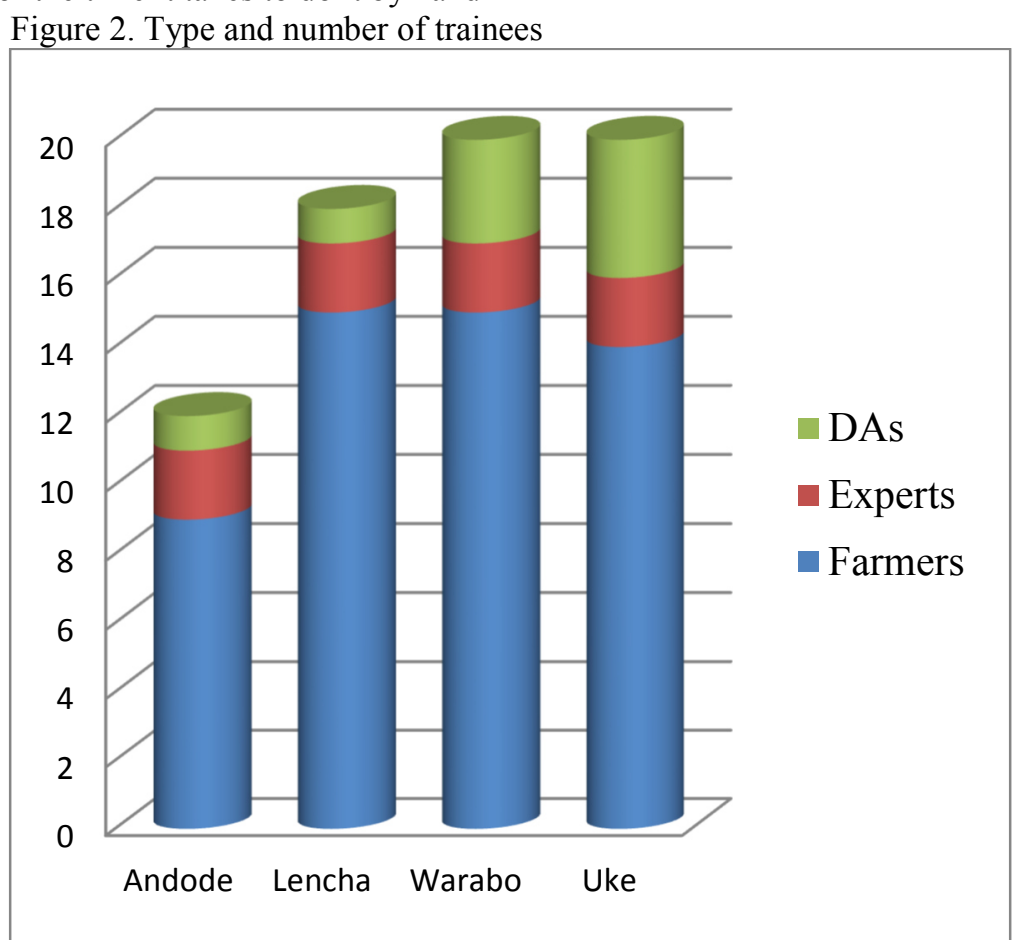

The training also touched the safety practices and procedures in machine operation. After the indoor lecture, trainees have proceeded to small field demonstration to complement the training with a practical exercise. During this session farmers were provided an opportunity to learn and operate soya bean thresher having guided by technician. Information on different components of the thresher, its general working principle and proper usage, precautionary measures, engine ignition and fuel supply system, installation, repair and maintenance schedule of thresher, have been shared

\section{Demonstration}

The thresher was carried from the workshop to the place where threshing would be performed and was installed on stable level ground in such a way that the wind was blow the straw and other impurities away from the clean grain. Before the start of the test, the thresher and engine was undergone a running for five minute without load to ensure whether all components functioned properly. The thresher was operated with the participation of members of the farmer research group, as well as other interested parties of the community. The occasion was attended by 60 farmers, 16 extension workers and 40 neighboring farmer. Participants were able to see engine driven soya bean thresher in action in a live demonstration and comparatively evaluated the machine against animal trampling and stick beating threshing system. This was the first time, where a thresher has been used for threshing of soya bean in these sites. Time savings, labor savings and grain quality (purity) were thresher's key characteristics collected from farmers and extensions agents at the end of the demonstration holding four FGDs under shaded areas of the field. Views and perception of participants on demonstrated thresher are included in sub title 3.4. 


\subsection{Experimental result}

Table 2. Experimental result

\begin{tabular}{l|l|l|l|l|l|l|l}
\hline Farm & $\begin{array}{l}\text { Whole crop } \\
\text { input in kg }\end{array}$ & $\begin{array}{l}\text { Mass of } \\
\text { threshed } \\
\text { grain k } \\
\left(\mathrm{Q}_{\mathrm{T}}\right)\end{array}$ & $\begin{array}{l}\text { Time of } \\
\text { threshing } \\
(\mathrm{min}) \\
\left(\mathrm{T}_{\mathrm{U}}\right)\end{array}$ & $\begin{array}{l}\text { Quantity of } \\
\text { un threshed } \\
\text { grain }(\mathrm{g}) \\
\left(\mathrm{Q}_{\mathrm{US}}\right)\end{array}$ & $\begin{array}{l}\text { Mass of } \\
\text { Broken grain } \\
(\mathrm{g}) \\
\left(\mathrm{Q}_{\mathrm{B}}\right)\end{array}$ & $\begin{array}{l}\text { Recommended } \\
\text { drum } \\
(\mathrm{rpm})\end{array}$ \\
\hline 1 & 200 & 155 & 17 & 7.30 & 3.30 & 700 \\
2 & 110 & 105 & 13 & 5.71 & 2.71 & 700 \\
3 & 120 & 100 & 10 & 4.98 & 2.20 & 700 \\
4 & 70 & 65 & 8 & 4.10 & 1.78 & 700 \\
Mean & 125 & 106.25 & 12 & 5.5 & 2.5 & 700 \\
SD & 54.46 & 37.05 & 3.92 & 1.33 & 0.66 & \\
\hline
\end{tabular}

Threshing capacity

Threshing efficiency

Mechanical damage
$550.5 \mathrm{~kg} / \mathrm{h}$

$85 \%$

Source: Author's field work computation (2010

Table 3 shows observations recorded to compute threshing efficiency, output capacity and breakage percentage of soybean thresher. Computation was made employing the index included in section 2.3. It is clear from the table that soya bean thresher has a capacity of about half quintals per hour and a threshing efficiency of 85 percent with the safer limit of breakage percent ranges 2 to 3. This findings is a bit less than the machine potential performance due to operator's skill the

\section{Time and labor cost saving effect of the soya thresher}

In order to make rough economic considerations based on farmers' perspective, the added value related to labor cost and time saving in machine threshing was compared relative to stick beating and animal hoofing. During computation the achieved threshing time of experiment was extrapolated to man-hour required per metric ton of soya bean grain. Data for this estimation was collected with three methods included individual survey, FGD, and measurement (Table 3 ) on the basis of custom hiring

Table 3. Labor cost and time consumed in threshing a ton of soybean grain by different methods

\begin{tabular}{|c|c|c|c|c|c|c|c|c|c|}
\hline \multirow[t]{3}{*}{ Data source } & \multicolumn{3}{|c|}{ Threshing capacity } & \multicolumn{3}{|c|}{$\begin{array}{l}\text { Time needed to thresh 1ton } \\
\text { with }\end{array}$} & \multicolumn{3}{|c|}{$\begin{array}{l}\text { Cost of labor to thresh } 1 \text { ton } \\
\text { with }\end{array}$} \\
\hline & $\begin{array}{l}\text { Animal } \\
\text { tramplin } \\
\mathrm{g}\end{array}$ & $\begin{array}{l}\text { Stick } \\
\text { beatin } \\
\mathrm{g}\end{array}$ & $\begin{array}{l}\text { Threshe } \\
\text { r }\end{array}$ & $\begin{array}{l}\text { Animal } \\
\text { tramplin } \\
\mathrm{g}\end{array}$ & $\begin{array}{l}\text { Stick } \\
\text { beatin } \\
\mathrm{g}\end{array}$ & $\begin{array}{l}\text { Threshe } \\
\mathrm{r}\end{array}$ & $\begin{array}{l}\text { Animal } \\
\text { tramplin } \\
\mathrm{g}\end{array}$ & $\begin{array}{l}\text { Stick } \\
\text { beatin } \\
\mathrm{g}\end{array}$ & $\begin{array}{l}\text { Threshe } \\
\mathrm{r}\end{array}$ \\
\hline & $\mathrm{Kg} / \mathrm{h}$ & $\mathrm{Kg} / \mathrm{h}$ & $\mathrm{Kg} / \mathrm{h}$ & $\mathrm{Hr}$ & $\mathrm{Hr}$ & $\mathrm{Hr}$ & birr & birr & birr \\
\hline $\begin{array}{l}\text { Measureme } \\
\text { nt }\end{array}$ & - & - & 550.5 & - & & 1.82 & - & - & 1051.5 \\
\hline Survey & 13.74 & 12.5 & - & 72.8 & 80 & - & 1870 & 2400 & - \\
\hline FGD & 10.99 & 10.42 & - & 91 & 96 & - & 1965 & 2650 & - \\
\hline
\end{tabular}

Remark: To calculate the above figure, the following information/assumptions were used;

The national average household size 4.8 persons,

National average of oxen holding 1.8

Assume 10-12 man-days /ton by stick beating

4-5 man-day-cum-8-9 oxen/ton for 8hour

Labor cost $=75 /$ day, Oxen rent $=30$

The farmer (service receiver) is expected to pay 75 Birr per hour as service fee

Meal $=50$ birr

Estimated threshing loss $=2.35 \%$ for thresher, $5 \%$ for traditional

Current price of soybean/quintal $=2300$

Time required for threshing one ton of soya bean with demonstrated soybean thresher was 1.82 hours whereas 88 and 82 hours on average with stick beating and animal based threshing carried out by 10 oxen-days and 4-5 man-days. This was only about 10 and $12 \%$ of the time that farmers reported spending on oxen trampling and stick beating respectively. That is in agreement with various researches that reported significant time is reduced on the process of threshing when mechanical means are employed. For using the demonstrated soya bean thresher, labor cost due to stick beating and animal trampling could also be saved by 60.3 and $46.5 \%$ respectively. The net 
labor cost saved per ton due to mechanical thresher was birr 913.5 and 1598.5 over beating and animal based threshing method correspondingly

\subsection{Perception and suggestion of farmers and extension workers on the threshers}

In pursuance of the third objective of this research work, elicitation of feedback from farmers, and agricultural extension agents on salient feature of soya bean thresher was carried out. Participant farmers considered themselves as lucky for getting the technology. They started over the machine with feeling of awe highlighting its intrinsic characteristics include speed of threshing which save time, the absence of animals in the threshing process, its ability to lower labor demand and crop loss which not capable of being accomplished by traditional methods. Many farmers were willing to purchase the threshing machine, from having seen or heard of it. Participant Extension workers and officials were also eminently satisfied with the function of the thresher and recognized the effort and cooperation of BAERC in the introduction of new technology.

However, the participant raised and discussed issues related to the access and the possibility of getting the technology. They called government to come to their aid by facilitating micro loan that help them purchase a technology provided that it would otherwise be unavailable. In fact, the farmer does not have to use the machine as a sole proprietor, since farmers can work in groups and use the thresher to generate income. The only two comments from farmers were in the area of mobility and safety. Farmers need the thresher in such a way that it is easily maneuverable because they can be used in any part of their field. It was propounded that the standard car wheels be used at its legs for easy transportation by donkeys. Elaborating further, they proposed to build a safety lever to prevent entrapping of hands by feed roller. A much more convincing remark was which suggests extra fan as they perceived that the machine mixes grain with straw.

\section{Conclusion and Recommendation}

In conclusion the technology demonstrated has observed to have an edge over conventional methods and thus very compelling to adopt by farmers. Besides, the feedback from farmers was unanimously affirmative. Hence based on the findings of this analysis and in particular the perception of farmers it was recommended that MoA should take the lead to further popularization of this threshing machine in the districts or outside that scope by providing soft loans for this purpose.

\section{References}

Alizadeh, M. R., \& Allameh, A. (2013). Evaluating rice losses in various harvesting practices. Int. Res. J. Appl. Basic Sciences, 4(4), 894-901.

Alizadeh, M. R., \& Allameh, A. (2013). Evaluating rice losses in various harvesting practices. Int. Res. J. Appl. Basic Sciences, 4(4), 894-901.

Alizadeh, M. R., \& Allameh, A. (2013). Evaluating rice losses in various harvesting practices. Int. Res. J. Appl. Basic Sciences, 4(4), 894-901

Manuwa, S. I. 2011. Properties of soya bean for best postharvest options. Soybean Physiology and Biochemistry, Prof. Hany El-Shemy (Ed.), ISBN: 978-953-307-534-1, In Tech, Available from: http://www.intechopen.com/books/soybean-physiology-and biochemistry/properties-of-soybean-forbestpostharvest-options (Accessed 12/10/2015

Asfaw, A, A. Teafaye, S, Alamrie, and M, Atnaf. 2011. Soya bean genetic improvement prospects. Proceedings of the workshop on food and forage legume, Ghion Hotel, Ethiopia

Boerma, H. R. and Specht, J. E., 2004. Soya bean: improvement, production and uses (No, Ed.3).

Sample Survey 2017/18: Report on Area and production of Major Crops (Private peasant Holdings, Meher Season

CSA (Central Statistical Agency of Federal Democratic Republic of Ethiopia), 20015-2019/20. Annual report. Ethiopian ATA \& USAID Investment Support Program (2013). "Immediate opportunity to invest in soybean meal processing for Ethiopia's booming livestock and poultry sectors".

Birhanu , Yalew M., and Adam B. (2018) ."Analysis of Cost and Return of Soybean Production under Small holder Farmers in Pawe District, North Western Ethiopia at Ethiopian Institute of Agricultural Research".

Burkill, I.H. 1935. A dictionary of the economic products of the Malay Peninsula, 1stEd. Dept. of Agriculture, Kuala Lumpur, Malaysia

CGIAR. 2005. CGIAR: Research and impact areas of research: soybean. www.cgiar.org/impact/research/soybean.html (accesed 14/07/2010)

EEA (Ethiopian Economic Association). 2015. Land tenure and agricultural development in Ethiopia. Ethiopia Economic Policy Research Institute, Addis Ababa, Ethiopia. (Available fromhttp://openlibrary.org/books/OL3738899M/Land tenure and agricultural development in Ethiopia) (Accessed on 1 September 2010).

FAO. (Food and Agricultural Organization of the United Nation). 2016. Food outlook. Oil Seeds Business Opportunities in Ethiopia, 2016; J.H.M. Wijnands, J. Biersteker, E.N. van Loo. 
GTP II (Growth and Transformation Plan II). Ministry of Agriculture and Rural Development Second Growth and Transformation Plan, Addis Ababa, Ethiopia.

Hailegiorgis, B. 2010. Export performance of oilseeds and its determinants in Ethiopia. Haramaya University, College of Agriculture and Environmental Science, Department of Agricultural Economics.

Manuwa, S. I. 2011. Properties of soybean for best postharvest options. Soybean Physiology and Biochemistry, Prof. Hany El-Shemy (Ed.), ISBN: 978-953-307-534-1, In Tech, Available from: http://www.intechopen.com/books/soybean-physiology-and biochemistry/properties-of-soybean-for-best post-harvest options (Accessed 12/10/2015

Khan M. A. (2010). In: Post Harvest Loss of soya bean( Khan S .L. editor). Trade Development Authority of Pakistan; Karachi, Pakistan.

Shurtleff, W., \& Aoyagi, A., 2009. History of soybeans and soy foods in Africa (1857-2009): Extensively annotated and bibliography and sourcebook. Soyinfo Center, Lafayette, California, USA. 